\title{
UTILIZATION OF SEWAGE WATER IN THE PRODUCTION OF INDUSTRIAL OIL AND FIBER FROM FLAX PLAN
}

\author{
El-Kassas, H. I. ${ }^{(1)}$; Abdel-Razek, T. A. M. ${ }^{(1)}$; Aissa, A. M. ${ }^{(2)}$; \\ Ahmed, S. H. ${ }^{(2)}$ and Gerges, Sh. H. S. ${ }^{(2)}$ \\ 1) Institute of Environmental Studies \& Research, Ain Shams University \\ 2) Soils, Water and Environmental Research Institute, A.R.C
}

\begin{abstract}
ABESTRACT
Reuse of treated waste water for agriculture enables fresh water to be exchanged for more economically and socially valuable purposes, while providing farmers with reliable and nutrient-rich water. This exchange also has potential environmental benefits, reducing the release of waste water effluent downstream and allowing the assimilation of its nutrients into the soil. If wastewater reuse was rejecting, the option could be costly in such situations. The aim of this study is to identify the suitability of primary treated sewage water alone or mixed with different rates of Nile water and their effects on soil properties and grown plants. So, field experiments with Randomized complete Block design were conducted in winter seasons of $2011 / 2012$ for flax crop, to study the effect of different water irrigation quality on the fiber yield and characters of sakha 2 flax cultivar at Balaks sewage water station,El- Qalioubia Governorate, Egypt. Results revealed that $100 \%$ sewage water recorded highest mean values of most flax characters such as total length, technical length, , No. of capsule / plant, No. of seeds / capsule, No. of benches / plant, fiber length and Iodine values, fiber yield per Fadden, fiber length, long fiber percentage and fiber fineness. On contrary, using $100 \%$ swage water caused significant decrease on fiber strength compared with those irrigated with $100 \%$ Nile water. The highest values of seeds yield, straw yield, fiber yield, weight of 1000 seeds, oil yield, fiber (\%) and seed oil (\%) were observed with irrigation $100 \%$ sewage water.
\end{abstract}

Key Words: flax, Kenaf, primary treated sewage water, industrial oils and fibbers. 
J. Environ. Sci.

Institute of Environmental Studies and Research - Ain Shams University

\section{INTRODUCTION}

Currently, Egypt produces an estimated 5.5- 6.5 Billion Cubic meters $\left(\mathrm{BCM}^{3}\right)$ of sewage water per year. Of that amount, about $2.97 \mathrm{BCM}^{3}$ per year is treated, but only $0.7 \mathrm{BCM}^{3}$ per year is utilized for agriculture. Where, 0.26 $\mathrm{BCM}^{3}$ is undergoing secondary treatment and $0.44 \mathrm{BCM}^{3}$ undergoing primary treatment, mainly direct reuse in desert areas or indirect reuse through mixing with agricultural drainage water (Abdel-Shafy and AbdelSabour,2006).

Flax (Linum usitatissium $L$ ) is the second important fiber crop after cotton in Egypt. It is grown for producing fibers only or seeds only, but in Egypt it is grown as dual purpose crop. Flax is the oldest fiber crop in Egypt. Flax is grown during winter season. In Egypt, flax cultivated area was about 35700 fedd. annually. Water is often the primary limiting factor in any crop production. Therefore, irrigation management is very important nowadays in Egypt due to the shortage in water resources as well as the expansion of agriculture in newly reclaimed lands (Hamada et al., 2009). The application of sewage water led to increased canola seeds yield but seed oil (\%) was decreased. Hussein et al., (2004) found that oil (\%) in seeds of cotton crop was decreased when irrigated by domestic sewage effluent Also, Oil (\%) in seeds was decreased in seeds of Safflower and rapeseed plants irrigated with sewage water more than that irrigated with Nile water (Abo-Rabeh,2011).

Flax is considered one of the most important dual purpose crops for oil and fiber production in Egypt and the world, flax seeds are rich in oil (41\%), protein (20\%), and dietary fiber (28\%) (Ibrahim, 2009). 
The current study aims at gaining more information about the effects and suitability of primary treated sewage water alone or mixed with different rates of Nile water on flax plant characteristics, fiber productivity and quality and oil yield.

\section{MATERIALS AND METHODS}

\section{Field experiment:}

To evaluate the effect of water quality on flax plant characteristics, fiber productivity and quality and oil yield. Field experiments were carried out at the Balaks in Mostored Potable water and Sanitation Company,Cairo, Egypt during winter 2012\& summer 2103.seeds of flax (Linum usitatissium L) was obtained from Fiber Crops Research Department, Field Crops Research Institute, Agriculture Research Center, Giza Egypt.

Seeds of flax were sown in 15 November 2012. The experimental plot area was $10 \mathrm{~m}$ of length $\mathrm{X} 4 \mathrm{~m}$ of width. The distance between rows was 10 $\mathrm{cm}$. Seeds yield at harvest was recorded in 15 May 2013. Each parts of plant samples were washed then dried at $70^{\circ} \mathrm{C}$.The dry materials were finely ground and kept in polyethylene bags for analysis.

\section{Analyses Technique:}

\section{Water analyses:}

Sewage water was collected from Balaks drain of Mostored city, Cairo Governorate, and mixed with different rates, $100 \%$ Nile water $\left(\mathrm{T}_{1}\right), 75 \%$ Nile water $+25 \%$ sewage water $\left(\mathrm{T}_{2}\right), 50 \%$ Nile water $+50 \%$ sewage water $\left(\mathrm{T}_{3}\right), 25 \%$ Nile water $+75 \%$ sewage water $\left(\mathrm{T}_{4}\right)$ and $100 \%$ Sewage water $\left(\left(\mathrm{T}_{5}\right)\right.$.

- pH values of irrigation water samples were determined (USDA, 1969). 
- Electrical conductivity (EC) of the irrigation water samples were measured using a conductivity bridge meter (USDA, 1969).

- Determination of Soluble ions (cations and anions) in irrigation water, according to the methods described by Black (1965).

-Determination of soluble heavy metals in irrigation water samples, according to the standard procedures (Greenberg et al.,1985).

- Determination of ammonia $\left(\mathrm{NH}_{4}^{+}\right)$and nitrate $\left(\mathrm{NO}_{3}{ }^{-}\right)$in irrigation water samples. by Auto Analyzer Instrument according to Tel (1982).

\section{Soil analyses:}

The collected soil samples before and after planting at different depths $(0-15 \mathrm{~cm}),(15-30 \mathrm{~cm})$ and $(30-45 \mathrm{~cm})$ were air dried, crushed and ground gently by a rod, sieved through a $2 \mathrm{~mm}$ sieve to get the fine particles, then kept in plastic bottles for analyses.

Table (1): Mean values of chemical analysis of Nile and primary treated sewage water

\begin{tabular}{|c|c|c|c|c|c|c|c|c|c|c|c|c|c|}
\hline \multirow{2}{*}{ Treatments } & \multirow{2}{*}{$\mathbf{p H}$} & \multirow{2}{*}{$\begin{array}{c}E C \\
(d S / m)\end{array}$} & \multicolumn{7}{|c|}{ Cations (meq $\mathrm{l}^{-1}$ ) } & \multicolumn{4}{|c|}{ Anions (meq $\left.\mathrm{l}^{-1}\right)$} \\
\hline & & & $\mathrm{Ca}^{++}$ & \multicolumn{2}{|c|}{$\mathbf{M g}^{++}$} & & & \multicolumn{2}{|c|}{$\mathbf{K}^{+}$} & $\mathrm{CO}_{3}{ }^{=}$ & $\mathrm{HCO}_{3}^{-}$ & $\overline{\mathrm{Cl}^{-}}$ & $\mathrm{SO}_{4}{ }^{=}$ \\
\hline $\begin{array}{c}\text { Primary } \\
\text { treated } \\
\text { sewage water }\end{array}$ & 7.99 & 2.73 & 8.24 & \multicolumn{2}{|c|}{7.95} & & & \multicolumn{2}{|c|}{0.03} & --- & 2.0 & 10.5 & 14.89 \\
\hline Nile water & 7.57 & 0.4 & 1.55 & \multicolumn{2}{|c|}{1.25} & & & \multicolumn{2}{|c|}{0.30} & --- & 1.0 & 2.5 & 1.20 \\
\hline \multirow{3}{*}{$\begin{array}{c}\text { Primary } \\
\text { treated } \\
\text { sewage water }\end{array}$} & \multicolumn{4}{|c|}{ Macronutrients (mg/l) } & \multicolumn{9}{|c|}{ Micronutrients and heavy metals (mg/l ) } \\
\hline & $\mathbf{N}$ & $\mathbf{P}$ & $\overline{\mathbf{K}}$ & & $\bar{F}$ & & $\mathbf{M}$ & & & $n$ & $\mathbf{P b}$ & $\mathbf{N i}$ & $\mathbf{C d}$ \\
\hline & 20.46 & 4.38 & 9.3 & & 0.8 & & 0.3 & & & 18 & 1.05 & 0.043 & 0.40 \\
\hline Nile water & 9.86 & 2.79 & 7.5 & & 0.2 & & 0.2 & & & 21 & 0.06 & 0.017 & 0.01 \\
\hline
\end{tabular}

Each value is a mean of three replicates. 


\section{A-Soil physical analysis:}

-Particle size distribution by the international pipette method according to Piper (1950). - Soil texture class was determined using the texture triangle diagram (Soil Survey Staff, 1962).

\section{B-Soil Chemical analyses:}

- Saturated soil paste \& saturation percentage (SP), (USDA, 1969).

- Soil reaction (pH) of saturated soil paste (Jackson, 1967).

- Electrical conductivity (EC): (USDA, 1969).

- Soluble cations $\left(\mathrm{Ca}^{+2}, \mathrm{Mg}^{+2}, \mathrm{Na}^{+}\right.$and $\left.\mathrm{K}^{+}\right)$and anions $\left(\mathrm{Cl}^{-}, \mathrm{CO}_{3}{ }^{-2,} \mathrm{HCO}_{3}{ }^{-}\right.$and $\mathrm{SO}_{4}^{-2}$ ) were determined in soil paste extract according to Page and Chang (1981).

- Determination of organic matter contents according to Walkley (1947).

- Determination of calcium carbonate contents: were determined using Collin's calcimeter (Wright, 1939). 
Table (2): Physical and chemical properties of studied soil before Flax planting.

\begin{tabular}{|c|c|c|c|c|c|c|c|c|c|}
\hline \multirow{2}{*}{$\begin{array}{c}\text { pH } \\
(1: 2: 5)\end{array}$} & \multirow{2}{*}{$\begin{array}{c}E C \\
(d \mathbf{S} / \mathbf{m})\end{array}$} & \multicolumn{4}{|c|}{ Cations (meq/l) } & \multicolumn{3}{|c|}{ Anions (meq/l) } & \multirow{2}{*}{ SAR } \\
\hline & & $\mathrm{Ca}^{++}$ & $\overline{\mathrm{Mg}^{++}}$ & $\mathrm{Na}^{+}$ & $\mathbf{K}^{+}$ & $\mathrm{HCO}_{3}{ }^{-}$ & $\mathrm{Cl}^{-}$ & $\mathrm{SO}_{4}{ }^{=}$ & \\
\hline 7.93 & 2.88 & 13.93 & 6.97 & 9.35 & 0.70 & 2.0 & 10.0 & 18.95 & 2.89 \\
\hline
\end{tabular}

\begin{tabular}{|c|c|c|c|c|c|c|c||}
\hline $\begin{array}{c}\text { Coarse sand } \\
(\%)\end{array}$ & $\begin{array}{c}\text { Fine sand } \\
(\%)\end{array}$ & $\begin{array}{c}\text { Silt } \\
(\%)\end{array}$ & $\begin{array}{c}\text { Clay } \\
(\%)\end{array}$ & Texture & $\begin{array}{c}\text { SP } \\
\%\end{array}$ & $\begin{array}{c}\text { O.M } \\
(\%)\end{array}$ & $\begin{array}{c}\mathrm{CaCO}_{3} \\
(\%)\end{array}$ \\
\hline 10.39 & $\mathbf{6 5 . 2 8}$ & $\mathbf{1 0 . 3 0}$ & $\mathbf{1 4 . 0 3}$ & Sandy loam & $\mathbf{2 2}$ & $\mathbf{0 . 4 4}$ & $\mathbf{2 . 1 9}$ \\
\hline \multicolumn{8}{|c|}{ Macronutrients (mg/kg) } \\
\hline \multicolumn{6}{|c|}{ P } & \multicolumn{3}{c||}{ K } \\
\hline Total & Avai. & Total & Avai. & Total & Avai. \\
\hline 65.94 & 34.89 & 12.88 & 3.75 & 482 & 180 \\
\hline
\end{tabular}

\begin{tabular}{||c|c|c|c|c|c|c|c|c|c|c|c|}
\hline \multicolumn{10}{||c|}{ Micronutrients and heavy metal contents mg/kg } \\
\hline \multicolumn{2}{|c|}{ Fe } & \multicolumn{2}{c|}{ Mn } & \multicolumn{2}{c|}{ Zn } & \multicolumn{2}{c|}{ Pb } & \multicolumn{2}{c|}{ Ni } & \multicolumn{2}{c|}{ Cd } \\
\hline To. & Avai & To. & Avai & To. & Avai & To. & Avai & To. & Avai & To. & Avai \\
\hline 784 & 2.25 & 280 & 1.39 & 23.88 & 4.87 & 19.79 & 2.13 & 17.34 & 1.23 & 4.85 & 0.23 \\
\hline
\end{tabular}

Each value is a mean of three replicates.

- Available nitrogen was extracted from soil using $2 \mathrm{~N} \mathrm{KCl}$ solution and was measured according to the modified Kjeldahal method (Page et al., 1982).

\section{C-Total and available heavy metals in the studied soils:}

- Total content of $\mathrm{Fe}, \mathrm{Mn}, \mathrm{Zn}, \mathrm{Cu}, \mathrm{Pb}, \mathrm{Ni}, \mathrm{Co}$ and $\mathrm{Cd}$ in soils were measured according to Jackson (1967).

- Available contents of $\mathrm{Fe}, \mathrm{Mn}, \mathrm{Zn}, \mathrm{Cu}, \mathrm{Pb}, \mathrm{Ni}$, and $\mathrm{Cd}$ in soils samples were extracted by ammonium bicarbonate diethylene triamine penta acetic acid 
(AB- DTPA).(1 N NH $4 \mathrm{HCO}_{3}+0.005 \mathrm{M}$ DTPA) buffered at pH 7.6 and 1: 2 soil : extracting solution ratio according to Soltanpour and Schwab (1977).

\section{Plant analysis:}

Seeds and straw Parts of the dry flax plant samples were wet digested using $\mathrm{H}_{2} \mathrm{SO}_{4}$ and $\mathrm{HClO} 4$ Jackson (1967).

- Contents of (N, P, K, Fe, Mn, Zn, Pb, Ni and Cd) were determined using the methods described by Jackson (1973) and Page et al. (1982).

- Protein percentage of seeds was calculated by multiplying the nitrogen percentage by the factor 6.25 (Hymowitz et al.,1972).

-Nitrogen was determined by Kjedahl method (Chapman and Partt, 1961).

- Phosphorus and microelements were determined by Page et al. (1982).

- Potassium was determined using Flame Photometer.

- Seed oil \% was determined by using Soxhlet apparatus and petroleum ether $\left(40-60^{\circ} \mathrm{C}\right)$ as a solvent according to A.O.A.C. (1990).

- Oil yield (ton/fed) was calculated by seed yield (t/ha) x seed oil (\%).

- Total plant length $(\mathrm{cm})$ was measured from soil surface to the highest point of plant.

- Technical length $(\mathrm{cm})$ was determined from soil surface to the first branch.

\section{- Retting process}

To separate fiber bundles from flax straw stem must be submerged in water at the ratio of 1: 13 (straw: water). This process takes about 10-12 days, where the fiber becomes easy separate from its stem.

- Fiber percentage was calculated by (weight of total fiber (g)/weight of straw after retting $(\mathrm{g})) \times 100$.

-Fiber yield (ton/fed) was calculated by straw yield (ton/fed) x fiber (\%). 
- Fiber fineness $(\mathrm{Nm})$ was calculated by $=\mathrm{NxL} / \mathrm{G}$. Where $\mathrm{N}=$ number of fibers (20 fibers each $10 \mathrm{~cm}$ ), $\mathrm{L}=$ length of fibers in $\mathrm{mm}, \mathrm{G}=$ weight of fibers in mgs (Radwan and A. Momtaz, 1966)

\section{Oil analysis:}

- Oil percent $(\%)=($ oil weight $) /($ weight of seeds $) \times 100)$

- Oil was analyzed according to American Oil Chemists' Society methods and the results ware compared with Standards of the EU "EN 14214",U.S."ASTM D6751" standard, and specifications for the German "DIN 51606" production of biodiesel.

- Iodine value (IV) for crude oil according to A.O.C.S. (1998).

- The obtained results were subjected to statistical analysis of variance according to method described by Snedecor and Cochran (1982).

\section{RESULTS AND DISCUSSION}

1-Water analysis: Data present in Table (3) showed that, the salinity (EC) ware 0.4, $0.98,1.78,2.11$ and $2.73 \mathrm{dS} / \mathrm{m}$ for $\mathrm{T}_{1}, \mathrm{~T}_{2}, \mathrm{~T}_{3}, \mathrm{~T}_{4}$ and $\mathrm{T}_{5}$, respectively.

Table (3): Mean values of Macronutrients, Micronutrients and heavy metals $(\mathrm{mg} / \mathrm{l})$ for the different irrigation water during Flax cultivation.

\begin{tabular}{|l|c|c|c|c|c|c|c|c|c|c|c|}
\hline \multirow{2}{*}{$\begin{array}{l}\text { Water } \\
\text { Quality }\end{array}$} & \multirow{2}{*}{$\begin{array}{c}\mathbf{E C} \\
\mathbf{d S m}^{-1}\end{array}$} & \multirow{2}{*}{$\mathbf{p H}$} & \multicolumn{4}{|c|}{$\begin{array}{c}\text { Macronutrients } \\
(\mathbf{m g} / \mathbf{l})\end{array}$} & \multicolumn{4}{|c|}{ Micronutrients and heavy metals (mg/l) } \\
\cline { 5 - 12 } & & & $\mathbf{N}$ & $\mathbf{P}$ & $\mathbf{K}$ & $\mathbf{F e}$ & $\mathbf{M n}$ & $\mathbf{Z n}$ & $\mathbf{P b}$ & $\mathbf{N i}$ & $\mathbf{C d}$ \\
\hline \hline $\left.\mathbf{( T}_{\mathbf{1}}\right)$ & 0.4 & 7.67 & 14.34 & 4.35 & 7.22 & 0.23 & 0.15 & 0.08 & 0.11 & 0.057 & 0.005 \\
\hline $\left.\mathbf{( T}_{\mathbf{2}}\right)$ & 0.98 & 7.61 & 15.98 & 4.77 & 7.63 & 0.34 & 0.21 & 0.21 & 0.35 & 0.093 & 0.020 \\
\hline $\left.\mathbf{( T}_{\mathbf{3}}\right)$ & 1.78 & 7.79 & 17.67 & 5.13 & 8.21 & 0.49 & 0.27 & 0.33 & 0.68 & 0.160 & 0.035 \\
\hline ( T4) & 2.11 & 7.84 & 19.12 & 5.61 & 8.89 & 0.61 & 0.31 & 0.85 & 0.82 & 0.222 & 0.042 \\
\hline ( T5) & 2.73 & 8.09 & 23.58 & 6.36 & 10.04 & 0.86 & 0.39 & 1.26 & 1.11 & 0.265 & 0.059 \\
\hline
\end{tabular}

Each value is a mean of three replicates. 
$\%$ The highest values of $\mathrm{N}, \mathrm{P}$ and $\mathrm{K}$ concentrations in $100 \%$ sewage water $\left(\mathrm{T}_{5}\right)$ were $23.58,6.36$ and $10.04 \mathrm{mg} / \mathrm{l}$,respectively. While, these concentrations were $14.34,4.35$ and $7.22 \mathrm{mg} / \mathrm{l}$ in100freshwater $\left(\mathrm{T}_{1}\right)$, respectively. Also, sewage water had the highest values of $\mathrm{Fe}, \mathrm{Mn}, \mathrm{Zn} \mathrm{Pb}, \mathrm{Ni}$ and $\mathrm{Cd}$ compared with freshwater.

\section{Effect of different water quality irrigation on soil properties fter flax harvest.}

\section{Soil pH:}

The effect of the sewage water and its different qualities due to dilution with different rates of fresh water after the period of flax cultivation on soil $\mathrm{pH}$ is shown in table (4). These values of surface soil layers $(0-15 \mathrm{~cm})$ after flax harvest were 8.03, 8.01, 7.95, 7.83 and 7.79 for $\left(T_{1}\right),\left(T_{2}\right),\left(T_{3}\right),\left(T_{4}\right)$ and $\left(\mathrm{T}_{5}\right)$, respectively. The results of study indicated that the application of sewage water to soil had decreased soil $\mathrm{pH}$ than initial soil. These results are in agreement with Mohammed et al. (2014) who indicated that the reason for decreasing of soil $\mathrm{pH}$ may be due to decomposition of organic matter and production of organic acids in soils irrigated with wastewater.

The soils of all the experimental treatments are characterized by slightly to moderately alkaline conditions, where the soil $\mathrm{pH}$ values is always around between 7.79 and 8.03 after flax harvest, according to Ayers \& Westcot, (1985) and Shaban (2005).

\section{Soil salinity (Electrical conductivity):}

Irrigation with sewage water led to increase soil salinity (E.C) as compared to the soil irrigated with freshwater. The obtained data in Table (4) show that $(\mathrm{EC})$ values of the surface soil $(0-15 \mathrm{~cm})$ were $2.75,2.92,3.14$, 
3.22 and $3.35 \mathrm{dS} / \mathrm{m}$ for $\left(\mathrm{T}_{1}\right),\left(\mathrm{T}_{2}\right),\left(\mathrm{T}_{3}\right),\left(\mathrm{T}_{4}\right)$ and $\left(\mathrm{T}_{5}\right)$, respectively. El- Gazzar (1996) came to the same conclusion.

\section{Soil organic matter \%:}

Organic matter in soil is the most important indicator of soil quality playing a major role in nutrient cycling; it increased as the proportion of primary sewage water increased in irrigation water. This is most likely to the higher organic matter content of waste water. Organic matter contents tend to be high in the surface layers than in the lower ones. Organic matter contents of soils in this study are still low due to their quick decomposition; this is a natural characteristic feature of semi-arid regions.

\section{Soil calcium carbonate\%:}

Date presented in Table (4) reported that, irrigation with waste water led to increase $\mathrm{CaCO}_{3} \%$. These results were reported also by Tabari and Salehi (2009).

\section{Macronutrients contents in the studied soil after flax harvest:}

Data in Table (4) showed that the irrigation with sewage water led to increase total and available $\mathrm{N}, \mathrm{P}$ and $\mathrm{K}\left(\mathrm{mg} \mathrm{kg}^{-1}\right)$ compared with fresh water, especially in surface layer $(0-15 \mathrm{~cm})$. This is a true; the sewage water had more enrichment in organic materials as well as N, P and K.

The highest increasing \% of total and available soil nitrogen by using $100 \%$ sewage water $\left(T_{5}\right)$ compared with those irrigated with $\left(T_{1}\right)$ were 24.68 and $35.33 \%$ While, the highest increasing \% of total and available phosphorus were 24.22 and $36.32 \%$. In the same context, the highest 
increasing $\%$ of total and available potassium were12.35 and $18.97 \%$ for the surface layers respectively, during the periods of flax cultivation.

Table (4): Effect of different irrigation water quality on some surface soil properties:

\begin{tabular}{|c|c|c|c|c|c|c|c|c|c|c|}
\hline \multirow{3}{*}{ Waterquality } & \multirow{3}{*}{$\underset{1: 2.5}{\text { pH }}$} & \multirow{3}{*}{$\begin{array}{c}\mathrm{EC} \\
\mathrm{dS} / \mathrm{m}\end{array}$} & \multirow{3}{*}{$\begin{array}{l}\text { O.M } \\
(\%)\end{array}$} & \multirow{3}{*}{$\begin{array}{c}\mathrm{CaCO}_{3} \\
(\%)\end{array}$} & \multicolumn{6}{|c|}{ Macronutrients $\mathrm{mg} / \mathrm{kg}$} \\
\hline & & & & & \multicolumn{2}{|c|}{$\mathbf{N}$} & \multicolumn{2}{|c|}{$\mathbf{P}$} & \multicolumn{2}{|c|}{$\mathbf{K}$} \\
\hline & & & & & Total & Avai & Total & Avai & Total & Avai \\
\hline$T_{1}$ & 8.03 & 2.75 & 0.42 & 2.05 & 65.71 & 38.55 & 12.88 & 3.80 & 486 & 195 \\
\hline$T_{2}$ & 8.01 & 2.92 & 0.68 & 2.22 & 68.86 & 47.39 & 14.36 & 3.89 & 513 & 198 \\
\hline$T_{3}$ & 7.95 & 3.14 & 1.02 & 2.31 & 74.98 & 49.52 & 14.76 & 4.01 & 528 & 204 \\
\hline $\mathbf{T}_{4}$ & 7.83 & 3.22 & 1.54 & 2.43 & 76.99 & 50.17 & 15.72 & 4.13 & 539 & 209 \\
\hline $\mathbf{T}_{5}$ & 7.79 & 3.35 & 1.87 & 2.65 & 81.93 & 52.17 & 16.00 & 5.18 & 546 & 232 \\
\hline
\end{tabular}

Each value is a mean of three replicates.

These results are in agreement with Kholdabakhsh et al., (2013) and Amin (2011) who indicated that the soil irrigated with waste water caused an increase of total and available $\mathrm{N}, \mathrm{P}$ and $\mathrm{K}$ of soil treated with waste water and this can be attributed to $\mathrm{N}, \mathrm{P}$ and $\mathrm{K}$ content in the wastewater.

\section{Micronutrients and heavy metals contents in the studied soil after flax harvest:}

The obtained data in Table (5) show that the soil content $\left(\mathrm{mgkg}^{-1}\right)$ of the tested micronutrients and heavy metals i.e. ( $\mathrm{Fe}, \mathrm{Mn}, \mathrm{Zn} \mathrm{Pb}, \mathrm{Ni}$ and $\mathrm{Cd}$ ) irrigated with $100 \%$ sewage water $\left(\mathrm{T}_{5}\right)$ or mixed with different rates of fresh water $\left(T_{4}, T_{3}\right.$ and $\left.T_{2}\right)$ after flax planting led to increase these heavy metals in soil surface in comparison with the soil irrigated with $100 \%$ fresh water $\left(\mathrm{T}_{1}\right)$. 
J. Environ. Sci.

Institute of Environmental Studies and Research - Ain Shams University

Table (5): Effect of different water quality on micronutrients and heavy metal contents in surface soil after Flax harvest.

\begin{tabular}{|c|c|c|c|c|c|c|c|c|c|c|c|c||}
\hline \multirow{2}{*}{$\begin{array}{c}\text { Water } \\
\text { quality }\end{array}$} & \multicolumn{8}{|c|}{ Micronutrients and heavy metal contents mg/kg } \\
\cline { 2 - 15 } & \multicolumn{2}{|c|}{ Fe } & \multicolumn{2}{|c|}{ Mn } & \multicolumn{2}{|c|}{ Zn } & \multicolumn{2}{c|}{ Pb } & \multicolumn{2}{|c|}{ Ni } & \multicolumn{3}{|c|}{ Cd } \\
\cline { 2 - 15 } & To. & Avai & To. & Avai & To. & Avai & To. & Avai & To. & Avai & To. & Avai \\
\hline \hline $\mathbf{T}_{\mathbf{1}}$ & 785 & 2.27 & 289 & 1.42 & 23.82 & 4.90 & 19.79 & 2.12 & 17.36 & 1.22 & 4.84 & 0.21 \\
\hline $\mathbf{T}_{\mathbf{2}}$ & 791 & 2.35 & 293 & 1.48 & 24.54 & 5.10 & 20.13 & 2.19 & 17.55 & 1.26 & 4.97 & 0.22 \\
\hline $\mathbf{T}_{\mathbf{3}}$ & 807 & 2.41 & 298 & 1.50 & 25.89 & 5.17 & 20.98 & 2.28 & 17.86 & 1.29 & 5.10 & 0.23 \\
\hline $\mathbf{T}_{\mathbf{4}}$ & 812 & 2.68 & 314 & 1.52 & 26.11 & 5.54 & 21.57 & 2.43 & 17.94 & 1.37 & 5.32 & 0.24 \\
\hline $\mathbf{T}_{\mathbf{5}}$ & 837 & 2.74 & 322 & 1.57 & 27.65 & 5.83 & 22.02 & 2.52 & 18.03 & 1.41 & 5.56 & 0.26 \\
\hline \hline
\end{tabular}

Each value is a mean of three replicates.

Total Fe values ranged from 785,791,807, 812and $837 \mathrm{mg} \mathrm{kg}^{-1}$ by using $\left(\mathrm{T}_{1}\right),\left(\mathrm{T}_{2}\right),\left(\mathrm{T}_{3}\right),\left(\mathrm{T}_{4}\right)$ and $\left(\mathrm{T}_{5}\right)$, respectively. The corresponding relative increases $\%$ of available Fe values compared with the same soil layer before the experiment were $0.13,0.89,2.93,3.57$ and $6.76 \%$ by using $\left(\mathrm{T}_{1}\right),\left(\mathrm{T}_{2}\right)$, $\left(\mathrm{T}_{3}\right),\left(\mathrm{T}_{4}\right)$ and $\left(\mathrm{T}_{5}\right)$, respectively.

Mean values of total and available $\mathrm{Mn}$ in the surface soils $(0-15 \mathrm{~cm})$ were $322 \mathrm{mg} / \mathrm{kg}$ and $1.57 \mathrm{mg} / \mathrm{kg}$ respectively due to irrigation with $100 \%$ waste water $\left(\mathrm{T}_{5}\right)$, while with the same soil irrigated by $100 \%$ fresh water $\left(\mathrm{T}_{1}\right)$ it were $289 \mathrm{mg} / \mathrm{kg}$ and $1.42 \mathrm{mg} / \mathrm{kg}$, with corresponding relative increases 14.42 and $10.56 \%$ respectively

Concerning the effect of irrigation of soils with waste water on total and available $\mathrm{Zn}$, data in Table (5) showed that values of $\mathrm{Zn}$ concentration were $23.82,24.54,25.89,26.11$ and $27.65 \mathrm{mg} \mathrm{kg}$ by using $\left(\mathrm{T}_{1}\right),\left(\mathrm{T}_{2}\right),\left(\mathrm{T}_{3}\right),\left(\mathrm{T}_{4}\right)$ and $\left(\mathrm{T}_{5}\right)$. The corresponding relative increases $\%$ of available $\mathrm{Zn}$ values in surface 78 
soil $(0-15 \mathrm{~cm})$ compared with the same soil layers before the experiment were $0.62,4.72,6.16,13.76$ and $19.71 \%$ by using $\left(\mathrm{T}_{1}\right),\left(\mathrm{T}_{2}\right),\left(\mathrm{T}_{3}\right),\left(\mathrm{T}_{4}\right)$ and $\left(\mathrm{T}_{5}\right)$, respectively.

Data presented in Table (5) showed that values of total $\mathrm{Pb}$ at soil irrigated with waste water through flax cultivation varied from 19.79, 20.13, 20.98, 21.57 and $22.02 \mathrm{mg} \mathrm{kg}^{-1}$ in the upper soil layers (0-15 cm depth), by irrigating with $\left(\mathrm{T}_{1}\right),\left(\mathrm{T}_{2}\right),\left(\mathrm{T}_{3}\right),\left(\mathrm{T}_{4}\right)$ and $\left(\mathrm{T}_{5}\right)$, respectively. The corresponding relative increases $\%$ of total $\mathrm{Pb}$ was $11.27 \%$ due to irrigated surface soil with $100 \%$ sewage water $\left(\mathrm{T}_{5}\right)$ compared with the same soil layers irrigated with $\left(\mathrm{T}_{1}\right)$. The relative increases $\%$ of available soil $\mathrm{Pb}$ were $3.30,7.75,14.62$ and $18.87 \%$ as a result of irrigated with $\left(\mathrm{T}_{2}\right),\left(\mathrm{T}_{3}\right),\left(\mathrm{T}_{4}\right)$ and $\left(\mathrm{T}_{5}\right)$, respectively and compared with $\left(\mathrm{T}_{1}\right)$

Concerning the effect of irrigation of soils with waste water on total and available $\mathrm{Ni}$, the relative increases $\%$ were 3.87 and $15.57 \%$, respectively. Due to irrigation with $100 \%$ waste water $\left(\mathrm{T}_{5}\right)$ and compared with $\left(\mathrm{T}_{1}\right)$.

As regard to total and available soil $\mathrm{Cd}$ contents as a result of irrigation with sewage water $\left(\mathrm{T}_{5}\right)$ were 5.56 and $0.26 \mathrm{mg} \mathrm{kg}^{-1}$ with relative increases \% 14.88 and $23.81 \%$ respectively, compared with the same soil irrigated by $\left(\mathrm{T}_{1}\right)$.

It is worthy to mention that the contents of all values of total and available heavy metals in the studied soil presented within safe or permissible limits and possible using these water sources for irrigation (FAO, 1992).

These results are in agreement with those reported by Rashad et al., (1995) for uncontaminated sandy soils of Egypt, 
J. Environ. Sci.

Institute of Environmental Studies and Research - Ain Shams University

\section{3- Effect of different irrigation water quality on flax plant:}

\section{Morphological characters:}

Data presented in Table (6) showed that increasing rates of sewage water led to increasing in all morphological characters than fresh water used for irrigation. The maximum values of total length $(\mathrm{cm})$, active plant length $(\mathrm{cm})$, fiber length $(\mathrm{cm})$, No. of capsule/plant, No. of seeds/capsule, No. of branches/plant and Iodine values (IV) were 96.59, 72.48, 79.51, 8.02, 5.82, 15.28 and 157.18 respectively, for soil irrigated with $100 \%$ sewage water $\left(\mathrm{T}_{5}\right)$. Also, the relative increases $\%$ of most morphological characters' values of flax plant in soil irrigated with 100 sewage water $\left(\mathrm{T}_{5}\right)$ compared with the same soil irrigated with $100 \%$ fresh water $\left(\mathrm{T}_{1}\right)$ were $28.56 \%$ for Total length; 31. $04 \%$ for Technical length, $25.65 \%$ for fiber length $16.74 \%$ for No. of capsule/plant; $28.76 \%$ for No. of seeds/capsule; $32.98 \%$ for No. of Branches/plant and $13.77 \%$ for Iodine values respectively

Table (6): Some characters of flax plant as affected by different water quality irrigation.

\begin{tabular}{|c|c|c|c|c|c|c|c|}
\hline \multirow{2}{*}{$\begin{array}{c}\text { Water } \\
\text { Quality }\end{array}$} & \multicolumn{7}{|c|}{ Characters } \\
\cline { 2 - 8 } & $\begin{array}{c}\text { Total } \\
\text { length } \\
(\mathbf{c m})\end{array}$ & $\begin{array}{c}\text { Technical } \\
\text { length } \\
(\mathbf{c m})\end{array}$ & $\begin{array}{c}\text { Fiber } \\
\text { length } \\
\text { (cm) }\end{array}$ & $\begin{array}{c}\text { No. of } \\
\text { capsules } \\
\text { /plant }\end{array}$ & $\begin{array}{c}\text { No. of } \\
\text { seeds/ } \\
\text { capsule }\end{array}$ & $\begin{array}{c}\text { No. of } \\
\text { branches } \\
\text { /plant }\end{array}$ & $\begin{array}{c}\text { Iodine } \\
\text { value }\end{array}$ \\
\hline $\mathbf{T}_{\mathbf{1}}$ & 75.13 & 55.31 & 63.28 & 6.87 & 4.52 & 11.49 & 138.15 \\
\hline $\mathbf{T}_{\mathbf{2}}$ & 85.81 & 57.73 & 69.45 & 7.03 & 4.86 & 12.69 & 143.27 \\
\hline $\mathbf{T}_{\mathbf{3}}$ & 89.83 & 64.02 & 73.04 & 7.40 & 5.11 & 14.00 & 148.97 \\
\hline $\mathbf{T}_{\mathbf{4}}$ & 92.48 & 69.33 & 75.73 & 7.88 & 5.19 & 14.62 & 152.26 \\
\hline $\mathbf{T}_{\mathbf{5}}$ & 96.59 & 72.48 & 79.51 & 8.02 & 5.82 & 15.28 & 157.18 \\
\hline \hline
\end{tabular}

Each value is a mean of three replicates. 


\section{Yield components of flax plant:}

Data obtained in Table (7). Showed that all the values of yield components of flax plants increased with increasing sewage water rates except for fiber fineness $(\mathrm{Nm})$

The highest values of seeds yield (ton/fed,) straw yield (ton/fed.) and fiber yield (ton/fed.) due to irrigation with $100 \%$ sewage water $\left(\mathrm{T}_{5}\right)$ were $0.65,2.43$ and 0.322 (ton/fed.) respectively, with increasing $18.18 \%, 10.96$ $\%$ and $23.85 \%$ respectively, comparing with those irrigated with fresh water $\left(\mathrm{T}_{1}\right)$. The height increases value of weight of 1000 seeds $(\mathrm{g})$ of flax plant was $7.16(\mathrm{~g})$, with irrigated $\left(\mathrm{T}_{5}\right)$, while this value was $5.69(\mathrm{~g})$ with the same plant irrigated by fresh water $\left(\mathrm{T}_{1}\right)$, with increase of $25.83 \%$.

Table (7): Yield of flax plant as affected of different water quality irrigation.

\begin{tabular}{|c|c|c|c|c|c|c|c|c|}
\hline \multirow{2}{*}{$\begin{array}{c}\text { Water } \\
\text { quality }\end{array}$} & $\begin{array}{c}\text { Seeds } \\
\text { yield } \\
\text { ton/fed. }\end{array}$ & $\begin{array}{c}\text { Straw } \\
\text { yield } \\
\text { ton/fed. }\end{array}$ & $\begin{array}{c}\text { fiber } \\
\text { yield } \\
\text { ton/fed. }\end{array}$ & $\begin{array}{c}\mathbf{1 0 0 0} \\
\text { seeds } \\
\text { Weight } \\
\text { (g) }\end{array}$ & $\begin{array}{c}\text { Oil } \\
\text { yield } \\
\text { ton/fed. }\end{array}$ & $\begin{array}{c}\text { Fiber } \\
(\%)\end{array}$ & $\begin{array}{c}\text { Fiber } \\
\text { fineness } \\
(\mathbf{N m})\end{array}$ & $\begin{array}{c}\text { Seed } \\
\text { Oil } \\
(\%)\end{array}$ \\
\hline \hline $\mathbf{T}_{\mathbf{1}}$ & 0.550 & 2.190 & 0.260 & 5.69 & 0.178 & 11.48 & 190.4 & 32.39 \\
\hline $\mathbf{T}_{\mathbf{2}}$ & 0.590 & 2.200 & 0.265 & 5.96 & 0.196 & 12.19 & 183.1 & 33.42 \\
\hline $\mathbf{T}_{\mathbf{3}}$ & 0.620 & 2.260 & 0.280 & 6.05 & 0.222 & 12.56 & 180.6 & 35.78 \\
\hline $\mathbf{T}_{\mathbf{4}}$ & 0.630 & 2.310 & 0.311 & 6.78 & 0.231 & 12.99 & 174.2 & 36.65 \\
\hline $\mathbf{T}_{\mathbf{5}}$ & 0.650 & 2.430 & 0.322 & 7.16 & 0.253 & 13.26 & 170.3 & 38.87 \\
\hline
\end{tabular}

Each value is a mean of three replicates.

On the other hand, the maximum values of oil yield (ton/fed.), fiber \%, and seed oil \% were 0.253 ton/ fed., $13.26 \%$, and $38.87 \%$, respectively due to the effect of irrigation with $100 \%$ waste water $\left(\mathrm{T}_{5}\right)$, which increased by $26.94 \%, 15.50 \%$ and $20.0 \%$ respectively, comparing with those irrigated with fresh water $\left(\mathrm{T}_{1}\right)$. 
Regarding fiber fineness (Nm), it decreased from 190.4 to 170.3 due to irrigation with100 \% waste water $\left(\mathrm{T}_{5}\right)$ comparing with those irrigated with fresh water $\left(\mathrm{T}_{1}\right)$, the decrease $\%$ was $11.8 \%$.

\section{Concentration and uptake of nutrients by flax plant:}

Nutrient contents in flax seeds were affected by irrigation of different water quality.

Data presented in Table (8) show that the highest concentration values (\%) of flax seeds were 3.91 for $\mathrm{N}, 0.35$ for $\mathrm{P}$ and 2.59 for $\mathrm{K}$ and the uptake values $(\mathrm{kg} / \mathrm{fed})$ were 214.0 for $\mathrm{N}, 24.0$ for $\mathrm{P}$ and 152.0 for $\mathrm{K}$ when irrigated with $100 \%$ sewage water $\left(\mathrm{T}_{5}\right)$.

The relative increasing $\%$ of $\mathrm{N}$ concentration in seeds of flax were 4.81 , 13.4, 22.68 and $34.36 \%$ as a result of irrigation with $\mathrm{T}_{2}, \mathrm{~T}_{3}, \mathrm{~T}_{4}$ and $\mathrm{T}_{5}$, respectively, compared with those irrigated with $100 \%$ fresh water $\left(\mathrm{T}_{1}\right)$.

The highest increasing \% of $\mathrm{P}$ and $\mathrm{K}$ concentration in seeds of flax when irrigated with $\left(\mathrm{T}_{5}\right)$ was 20.69 and $17.73 \%$ respectively, compared with those irrigated with $\left(\mathrm{T}_{1}\right)$.

$\mathrm{N}, \mathrm{P}$ and $\mathrm{K}$ uptake in seeds of flax were $214.0,24.0$ and $152.0 \mathrm{~kg} / \mathrm{fed}$, respectively, when irrigated with $\left(\mathrm{T}_{5}\right)$, with relative increasing \% 18.89, 26.32 and $21.6 \%$, respectively comparing with those irrigated with $\left(\mathrm{T}_{1}\right)$.

\section{Micronutrients concentration and uptake in seeds of flax plant:}

The relative increase $\%$ of $\mathrm{Fe}$ concentration and uptake in seeds of flax irrigated with $\left(\mathrm{T}_{5}\right)$ compared with the same seeds irrigated with $\left(\mathrm{T}_{1}\right)$, were 22.28 and $26.07 \%$, respectively, as shown in (Table 9). While, the highest 
increase $\%$ of Mn concentrations and uptake values were 22.26 and $33.32 \%$ respectively, due to irrigation with $\left(\mathrm{T}_{5}\right)$.

Table (8): Macronutrients concentration and uptake in flax seeds as affected by different water quality irrigation.

\begin{tabular}{|c|c|c|c|c|c|c|}
\hline \multirow{3}{*}{$\begin{array}{c}\text { Water } \\
\text { Quality }\end{array}$} & \multicolumn{6}{|c|}{ Macronutrients in seeds flax plant } \\
\cline { 2 - 7 } & $\begin{array}{c}\text { Conc. } \\
(\boldsymbol{\%})\end{array}$ & $\begin{array}{c}\text { Uptake } \\
(\mathbf{k g} / \mathbf{f e d})\end{array}$ & $\begin{array}{c}\text { Conc. } \\
(\boldsymbol{\%})\end{array}$ & $\begin{array}{c}\text { Uptake } \\
(\mathbf{k g} / \mathbf{f e d})\end{array}$ & $\begin{array}{c}\text { Conc. } \\
(\boldsymbol{\%})\end{array}$ & $\begin{array}{c}\text { Uptake } \\
(\mathbf{k g} / \mathbf{f e d})\end{array}$ \\
\hline $\mathbf{T}_{\mathbf{1}}$ & 2.91 & 180.0 & 0.29 & 19.0 & 2.20 & 125.0 \\
\hline $\mathbf{T}_{\mathbf{2}}$ & 3.05 & 189.0 & 0.30 & 20.0 & 2.30 & 133.0 \\
\hline $\mathbf{T}_{\mathbf{3}}$ & 3.30 & 200.0 & 0.31 & 21.0 & 2.45 & 142.0 \\
\hline $\mathbf{T}_{\mathbf{4}}$ & 3.57 & 209.0 & 0.33 & 22.0 & 2.53 & 147.0 \\
\hline $\mathbf{T}_{\mathbf{5}}$ & 3.91 & 214.0 & 0.35 & 24.0 & 2.59 & 152.0 \\
\hline
\end{tabular}

Each value is a mean of three replicates.

In the same context, the highest values of $\mathrm{Zn}$ concentration and uptake in seeds irrigated with $\left(\mathrm{T}_{5}\right)$ were $37.53 \mathrm{mg} / \mathrm{kg}$ and $22.54 \mathrm{~g} / \mathrm{fed}$., respectively in seeds of flax plants with the relative increases $13.66 \%$ for $\mathrm{Zn}$ concentration and $24.12 \%$ for uptake respectively, compared with the same seeds irrigated with $\left(\mathrm{T}_{1}\right)$,

\section{Heavy metals concentration and uptake in seeds of flax plant:}

The highest values of $\mathrm{Pb}$ concentration and uptake in flax seeds were $0.83 \mathrm{mg} / \mathrm{kg}$ and $21.90 \mathrm{~g} / \mathrm{fed}$ respectively, when irrigated with $\left(\mathrm{T}_{5}\right)$. The corresponding relative increasing \% of $\mathrm{Pb}$ concentration and uptake in seeds of flax plants comparing the highest values and lower ones due to irrigation with fresh water $\left(T_{5}\right)$ were 20.29 and $29.59 \%$. These results are in agreement with Bjelkova et al., (2011) who found that the application of sewage sludge on absorption of $\mathrm{Pb}$ in seeds of flax increased with increasing the same metals in sewage sludge applied. 
Table (9): Micronutrients and heavy metals concentration and uptake in flax seeds plant as affected by different water quality irrigation.

\begin{tabular}{|c|c|c|c|c|c|c|c|c|c|c|c|c|}
\hline \multirow{3}{*}{$\begin{array}{l}\text { Water } \\
\text { quality }\end{array}$} & \multicolumn{12}{|c|}{ Micronutrients and heavy metals in flax plant seeds } \\
\hline & \multicolumn{2}{|c|}{$\mathbf{F e}$} & \multicolumn{2}{|c|}{ Mn } & \multicolumn{2}{|c|}{$\mathbf{Z n}$} & \multicolumn{2}{|c|}{$\mathbf{P b}$} & \multicolumn{2}{|c|}{$\mathbf{N i}$} & \multicolumn{2}{|c|}{$\mathbf{C d}$} \\
\hline & $\begin{array}{l}\text { Conc. } \\
\mathrm{mg} / \mathrm{kg}\end{array}$ & $\begin{array}{l}\text { Uptake } \\
\text { g/fed }\end{array}$ & $\begin{array}{l}\text { Conc. } \\
\mathrm{mg} / \mathrm{kg}\end{array}$ & $\begin{array}{l}\text { Uptake } \\
\text { g/fed }\end{array}$ & $\begin{array}{l}\text { Conc. } \\
\mathrm{mg} / \mathrm{kg}\end{array}$ & $\begin{array}{c}\text { Uptake } \\
\text { g/fed }\end{array}$ & $\begin{array}{l}\text { Conc. } \\
\mathrm{mg} / \mathrm{kg}\end{array}$ & $\begin{array}{l}\text { Uptake } \\
\text { g/fed }\end{array}$ & $\begin{array}{l}\text { Conc. } \\
\mathrm{mg} / \mathrm{kg}\end{array}$ & $\begin{array}{c}\text { Uptake } \\
\text { g/fed }\end{array}$ & $\begin{array}{l}\text { Conc. } \\
\mathrm{mg} / \mathrm{kg}\end{array}$ & $\begin{array}{l}\text { Uptake } \\
\text { g/fed }\end{array}$ \\
\hline $\mathbf{T}_{1}$ & 140.83 & 74.15 & 43.30 & 25.81 & 33.02 & 18.16 & 0.69 & 16.90 & 0.94 & 3.20 & 0.69 & 2.21 \\
\hline $\mathbf{T}_{2}$ & 142.99 & 77.34 & 44.32 & 26.15 & 33.90 & 19.20 & 0.70 & 17.50 & 0.97 & 3.40 & 0.72 & 2.39 \\
\hline $\mathbf{T}_{3}$ & 156.82 & 79.83 & 46.52 & 28.84 & 34.98 & 20.91 & 0.73 & 18.20 & 1.10 & 3.68 & 0.76 & 2.64 \\
\hline $\mathbf{T}_{4}$ & 163.75 & 82.06 & 50.73 & 31.96 & 36.02 & 21.62 & 0.79 & 19.60 & 1.15 & 3.909 & 0.81 & 2.82 \\
\hline $\mathbf{T}_{5}$ & 172.21 & 93.48 & 52.94 & 34.41 & 37.53 & 22.54 & 0.83 & 21.90 & 1.24 & 4.05 & 0.83 & 2.84 \\
\hline
\end{tabular}

Each value is a mean of three replicates.

Regarding data presented in Table (9) show that, applying sewage water in irrigation caused markedly increases in the concentration and uptake of $\mathrm{Ni}$, the relative increase $\%$ of $\mathrm{Ni}$ concentration and uptake in seeds of flax plant under irrigation with different rates of sewage water were 22.34 and $15.0 \%$ respectively, in plot irrigated with $\left(\mathrm{T}_{3}\right)$ and were 31.91 and $26.56 \%$ respectively in plot irrigated with $\left(\mathrm{T}_{5}\right)$, compared with $\left(\mathrm{T}_{1}\right)$.

Kabata-Pendias and Pendias (1992) showed that Ni toxic limits ranged from $10-100 \mathrm{ug} \mathrm{Ni} / \mathrm{g}$ plant. The highest increase $\%$ of $\mathrm{Cd}$ concentration for flax seeds was $20.29 \%$. While the relative increase $\%$ of $\mathrm{Cd}$ uptake were 28.51 , due to irrigation with $100 \%$ waste water $\left(\mathrm{T}_{5}\right)$. Compared with the same seeds irrigated with $100 \%$ fresh water $\left(\mathrm{T}_{1}\right)$. 
Finally, the use of primary treated sewage water in this study achieved high environmental values, enables freshwater to be exchanged for more economically and socially valuable purposes. The morphological study characters of flax plant included plant length, Active plant length, fiber length, No. of capsule/plant, No. of seeds/capsule, No. of benches/plant and Iodine values ( IV) were increased by irrigating with treated sewage water in all morphological characters than fresh water, weight of plant yields and straw yield, weight of fiber yield were increased by irrigating with sewage water comparing with those irrigated with fresh water. The height increases value of weight of 1000 seeds, maximum values of oil yield, fiber $\%$ and seed oil $\%$ were increased by irrigating with treated sewage water. The highest values of $\mathrm{N}, \mathrm{P}$ and $\mathrm{K}$ concentration and uptake were found with waste water irrigation. From the distribution of micronutrients and heavy metals concentrations in flax plant, there is no doubt that irrigation with waste water was within safe and permissible limits and it is possible to using these water sources for irrigation in the studied soils according to FAO (1992) for waste water treatments and use in agriculture.

\section{REFERENCES}

Abdel-Shafy, H.I. and Abdel-Sabour, M.F. (2006): Waste water reuse for irrigation on the desert sandy soil of Egypt: long-term Effect. In P. Hlavinek et al. (Eds): Integrated Urban Water Resources Management, Springer Publishers, Netherland, pp.301-312.

Abo-Rabeh. R. A. A. (2011): Evaluation of waste water quality for irrigating of some oil crops. M.Sc.Thesis, Institute of Environmental Studies \& Research , Ain Shams Univ .Egypt. 
Amin, M. (2011): Effect of municipal waste water on physical and chemical properties of saline soil. J. Biol. Environ. Sci. 5 (14): 71- 76.

A.O.A.C.,(1990): Official Methods of the Association of Official Analysis Chemists (K. Helssch, ed) A.O.A.C. Inc., 15th . Edition, Virginia, U.S.A 9- 64.

A.O.C.S (1998): Official Methods and Recommended Practices Of The American Oil Chemists' Society. Fited American oil chemisits champaingn IL.

Ayers, R.S. and westcot, D.W. (1985): Water quality for agriculture irrigation and drainage". Rev. 1 Food and Agric. Organ. of U.N., Rome, pp. 29.

Bjelkova, M.; Vectrovcova, M.; Griga, M. and Skarpa, P (2011): Effect of sewage sludge in soil on $\mathrm{Cd}, \mathrm{Pb}$ and $\mathrm{Zn}$ accumulation in Linum usitatissimum L. Proceedings of Ecopole J. 5 (1): 21- 27.

Black, C. A. (1965): Methods of soil analysis. Soil Sci. Soc. of America., Inc. Pub. Madison, Wisconsin, USA.

Bybordi, A. and G. Mamedov, (2010): Evaluation of application methods efficiency of Zinc and Iron for Canola (Brassica napus L.). Not. Sci. Biol., 2(1): 94-103.

Chapman, H.D. and P.F. Pratt, 1961. "Methods of Analysis for Soils, Plants and Water". Agric. Publ. Univ., of California, Riverside.

El- Gazzar, A. L (1996): " Use of low quality water in irrigation and its effect on soil properties". Ph.D. Thesis, Fac. of Agric. at Moshtohor, Zagazig Univ., Egypt

FAO (1992): Waste water treatment and use in agriculture. FAO Soils Bull. No.47, Rome.

Greenberg, A.E; R . R . Trussell and Lenore, S . C (1985): Standard methods for examination of water and waste water. Washington, APHA, AWWA and WPCF. DC, USA.

Hamada, E.; Mohamed, Kh. And Mohamed, M. (2009): Utilization of seed drill machine for planting flax crop and irrigation water management. Misr. J. Agric. Eng. 26 (3): 1120 - 1137. 
Hussein, H.F., Saber, M.S. M. , Radwan, S.M.A. and Abu- Seda, M. (2004): Use of treated domestic sewage effluent for growing summer oil in arid lands. Inter. Conf. on Water Resource and Arid Envir.: 116.

Hymowitz, T.F., P. Collins and W.M. Walker, (1972): Relationship between the content of oil, protein and sugar in soybean seed. Agron. J., 64: 613-616.

Ibrahim, H.M.(2009): Effect of sowing date and N-fertilizer levels on seed yield, some yield components and oil content in flax. Alex. J. Agric. Res. Egypt 54(1): 19- 28.

Jackson, M. L. (1967): Soil Chemical Analysis. Prentice- Hall, Inc. N. J. USA.

Jackson, M.L., (1973): Soil Chemical Analysis". Prentice Hall Inc., Englewood Cliffs, N. J., USA.

Kabata- Pendias, A. and Pendias, H. (1992): Trace Elements in Soils and plants. $2^{\text {nd }}$ Ed. CRC Press, Inc. Boca Raton Ann Arbor London.

Khodabakhsh, P.K.; Sadighbeh, N. S. and Abdohossin, S. (2013): Soil chemical properties affected by application of treated municipal waste water. Annals of Biological. Res. 4 (3): 105- 108.

Mohammed, A.A., Lathamani, R. and Sidduraiah, S. (2014): Effect of sewage water irrigation on soil properties and evaluation of accumulation of elements in Grass crop in Mysore City, Karnataka, India. American J. of Envio. Protection. 3 (5): 283- 291.

Page, A. L. and Chang, A. C. (1981): Trace metals in soils and plants receiving municipal irrigation. In: (F. M. D' Itri, J. A. Martinez and M. A. Lambarri, eds) Municipal Waste water in Agriculture. Academic Press, pp. 351- 372.

Piper, C. S. (1950): Soil and plant analysis. Inter. Sci. Publishers, Inc. New York , USA.

Radwan, S.R.H and A. Momtaz (1966): The Technological properties for flax fibers and methods of estimating them. El-felaha J.46 (5): 466-476 (in Arabic) . 
Rashad, I. F.; Abdel-Nabi, A. O.; El-Hemely, M. E. and Khalaf, M. A. (1995): Back ground levels of heavy metals in Nile delta soils. Egypt. J. Soil. Sci. 35, (2): 239-252.

Shaban ,H.A. Kh. (2005): Effect of Irrigation Water Resources on Properties and Productivity of Salt Affected Soil. Ph. D. Thesis Fac .of Agric, Minufiya Univ .Egypt,pp.273-276.

Snedecor, G.W. and W. G. Cochran, (1982): Statistical methods. 7thEd. Iowa State Press Iowa, USA.

Soil Survey Staff (1962): Soil survey manual. U.S. D.A. Hand Book, No, 18. Washington D.C., USA

Soltanpour, P. N. and A. P. Schwab (1977): A new test for simulatoneous extraction of macro and micro- nutrients in alkaline soils. Commun. Soil Sci. Plant Anal. 8: 195-207.

Tabari M. and Salehi A . (2009): The use of municipal waste water in afforestation: effects on soil properties and Eldar pine trees. Polish J. of Environ. Stud. 18 (6) : 1113-1121

Tel, D. A.(1982): Determining Nitrate, Nitrite and Ammonium in Soil extracts (Technicon All) Automated and semi- automated methods for soil and plant analysis. 7:8 -13.

USDA (1969): Diagnosis and Improvement of Saline and Alkali Soil. U.S. Salinity Laboratory staff, United States Department of Agriculture. (USDA), Handbook 2nd Ed. 60., USA.

Walkley, A. (1947): A critical examination of rapid method for determining organic carbon in soils. Effect of valuations in digestion conditions and inorganic soil constituents. Soil Sci., 63: 251-264

Wright, C. H. (1939): Soil Analysis. Thomas Marley \& Co. London, U.K. 


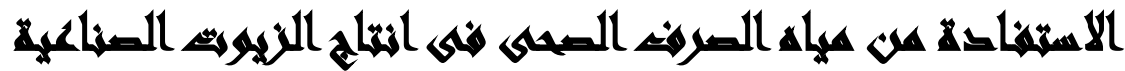

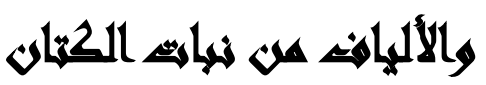

[0]

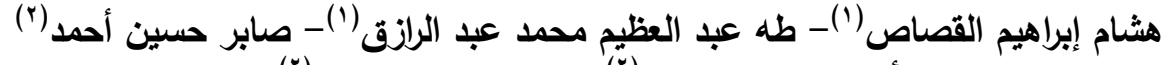

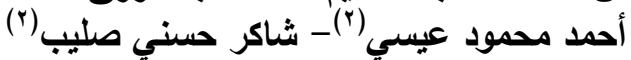

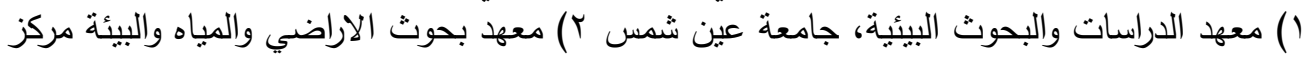

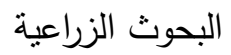

\section{المستخله}

تهدف هذه الدراسة لتقييم صلاحية مياه الصرف الصحى المعالجة أوليا فى إنتاج محاصيل زيتية

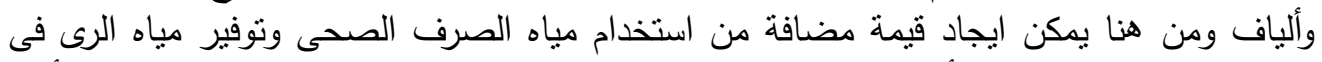

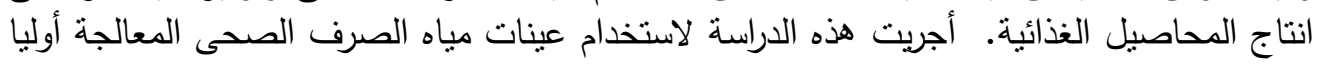

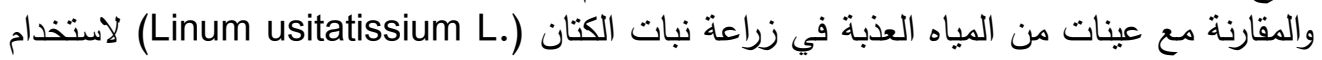
زيوتها كزيوت صناعية والاستفادة من اليافها.

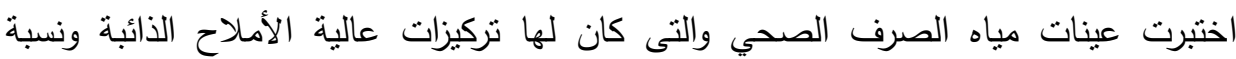

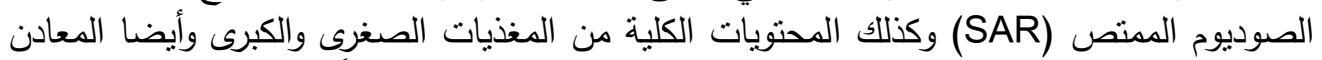

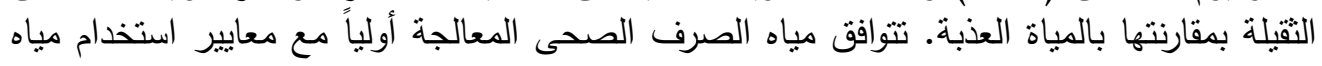

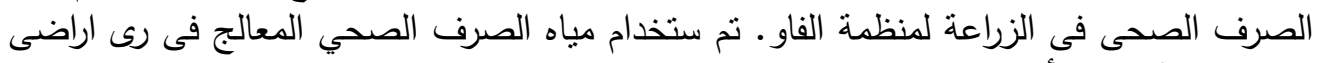

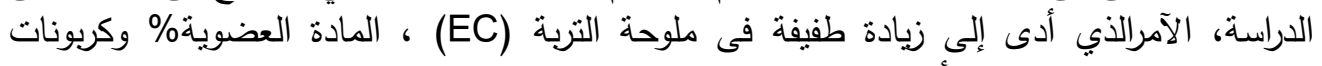

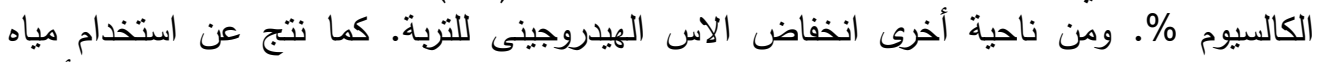

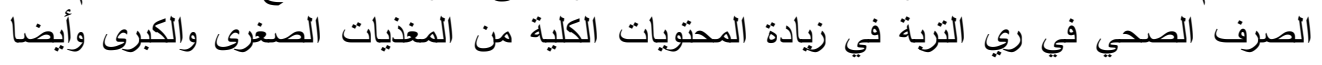

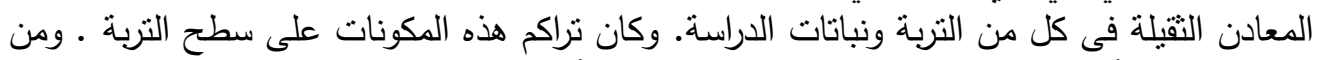

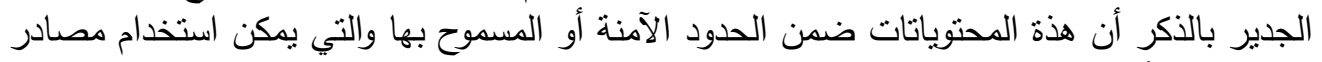

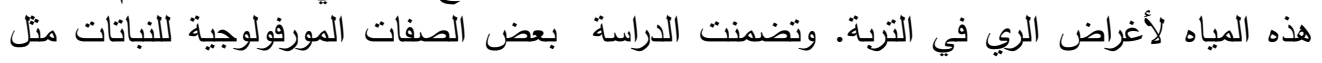

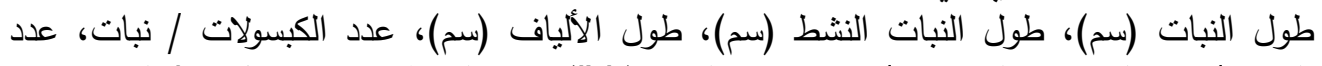

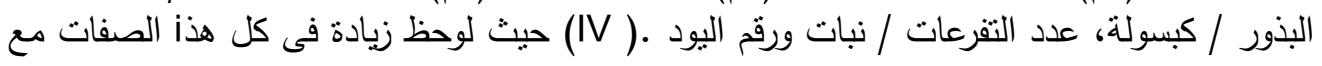

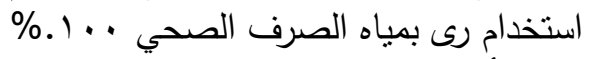

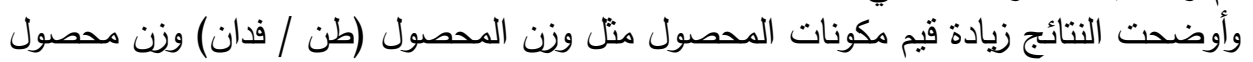

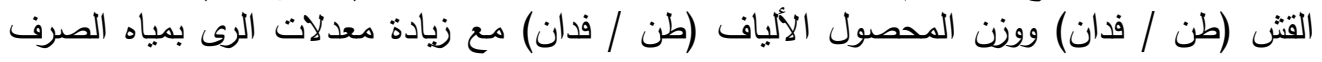

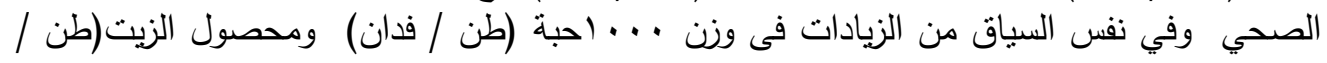

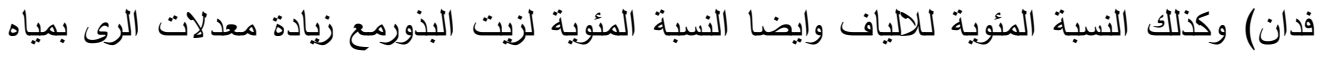

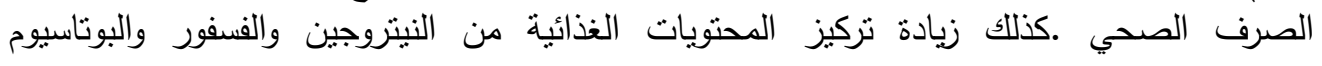


J. Environ. Sci.

Institute of Environmental Studies and Research - Ain Shams University

لبذورالكتان مع نوعية مياه الري وكذلك امتصاص النبات لهذه العناصر والتى زادت مع تزايد معدل

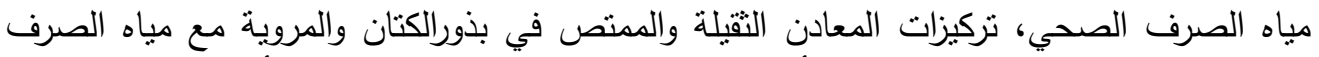

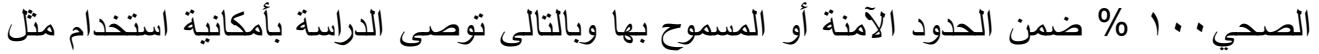

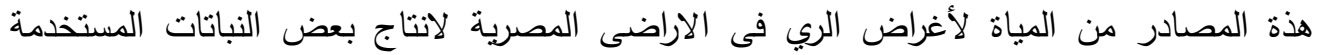
لانتاج الزيوت الصناعية والالياف بمعايير وتحت دراسات مقنتة لإضئ. 